\title{
Tinjauan Lama Waktu Penyediaan Rekam Medis Pasien Rawat Jalan Klinik Kandungan di RSUD Tebet
}

\section{Overview of The Length of Time for Providing Medical Records for Outpatients at The Obstetry Clinic in RSUD Tebet}

\author{
Annida Ariyani ${ }^{1}$, Laela Indawati ${ }^{2}$, Puteri Fannya ${ }^{3}$, Nanda Aula Rumana ${ }^{4}$ \\ 1,2,3,4 Universitas Esa Unggul \\ Jalan Arjuna Utara No.9, Kb. Jeruk, Kec. Kb. Jeruk, Kota Jakarta Barat \\ *e-mail korespondensi: anindaariyani20@gmail.com
}

\begin{abstract}
Abstrak
Waktu penyediaan dokumen rekam medis pasien rawat jalan merupakan salah satu indikator mutu pelayanan rekam medis. Semakin cepat penyediaan dokumen rekam medis sampai ke klinik maka semakin cepat pula pelayanan yang diberikan kepada pasien. Tujuan dalam penelitian ini adalah mengetahui waktu penyediaan rekam medis rawat jalan klinik kandungan di RSUD Tebet. Metode penelitian yang digunakan adalah metode deskriptif kuantitatif yaitu dengan mendapatkan informasi penelitian berdasarkan wawancara dan hasil observasi. Sampel penelitian ini adalah rekam medis pasien rawat jalan klinik kandungan berjumlah 105 rekam medis, menggunakan teknik pengambilan sampel (Incidental/Convenience Sampling). Hasil dari penelitian ini dapat diketahui 48 rekam medis $(45,71 \%)$ telah sesuai dengan Standar Prosedur Operasional $\leq 15$ menit, sedangkan 57 rekam medis $(54,28 \%)$ belum sesuai Standar Prosedur Operasional $>15$ menit dengan rata-rata waktu penyediaan rekam medis 15,67 menit. Waktu tercepat adalah 10 menit dan waktu terlama adalah 25 menit. Kesimpulan dari hasil penelitian ini adalah petugas rekam medis bagian pelayanan berkas di RSUD Tebet belum sesuai dengan Standar Prosedur Operasional yang ada. Faktor penyebab keterlambatan dalam penyediaan rekam medis kapasitas rak penyimpanan sudah penuh, sering ditemukan rekam medis menempel dengan rekam medis lain, letak ruang penyimpanan yang terpisah menjadi 2, belum dikembalikannya rekam medis rawat inap ke ruang penyimpanan. Sebaiknya petugas rekam medis bagian pelayanan berkas untuk menyediakan rekam medis dengan tepat waktu sesuai Standar Prosedur Operasional yang telah di tetapkan dan perlu mensosialisasikan kembali kepada perawat ruangan rawat inap tentang ketepatan pengembalian rekam medis dalam waktu 1x24 jam sesuai dengan Standar Prosedur Operasional.
\end{abstract}

Kata kunci: Lama waktu, Waktu penyediaan, Rekam medis, Rawat jalan, Klinik kandungan

\begin{abstract}
The time ensuring provision of outpatient medical records is one indicator of the quality of medical record services. The faster provision of medical records to document the faster clinic services provided to patients. The purpose of this study was to determine the time of providing outpatient medical records at the obstetrics clinic at RSUD Tebet. The research method used is descriptive quantitative method, namely by obtaining research information based on interviews and observations. The sample of this study was the medical records of outpatients in obstetrical clinics totaling 105 medical records, using a sampling technique (Incidental/Convenience Sampling). The results of this study can be seen that 48 medical records $(45,71 \%)$ are in accordance with Standard Operating Procedures 15 minutes, while 57 medical records $(54,28 \%)$ are not in accordance with Standard Operating Procedures $>15$ minutes with an average time of providing records medical 15.67 minutes. The fastest time is 10 minutes and the longest time is 25 minutes. The conclusion from the results of this study is that the medical record officer in the file service section at RSUD Tebet is not in accordance with the existing Standard Operating Procedures. Factors causing delays in the provision of medical records storage rack capacity is full, medical records are often found attached to other medical records, the location of the storage room is separated into 2 , the inpatient medical records have not been returned to the storage room. It is recommended that the medical record officer in the
\end{abstract}

p-ISSN: | e-ISSN: 2807-2596

website: ijhim.stikesmhk.ac.id/index.php/ 
file service section provides medical records in a timely manner according to the established Standard Operating Procedures.

Keywords: Length of time, Time for providing, Medical records, Outpatient, Obstetry clinic

\section{PENDAHULUAN}

Rumah Sakit adalah sarana kesehatan yang menyelenggarakan pelayanan kesehatan perorangan meliputi pelayanan promotif, preventif, kurative dan rehabilitatif yang menyediakan pelayanan rawat inap, rawat jalan, dan gawat darurat. Rumah Sakit berdasarkan Peraturan Menteri Kesehatan Republik Indonesia Nomor:340/MENKES/PER/III/2010 merupakan suatu intitusi pelayanan kesehatan yang menyelenggarakan pelayanan kesehatan perorangan secara paripurna yang menyediakan pelayanan rawat inap, rawat jalan pasien lama dan gawat darurat (Kemenkes RI, 2010).

Word Health Organization (WHO) menyebutkan rumah sakit diberikan batasan yaitu suatu bagian menyeluruh dari organisasi sosial dan medis, yang berfungsi memberikan pelayanan kesehatan lengkap kepada masyarakat baik kuratif maupun rehabilitatif, dengan suatu pelayanan yang dapat menjangkau pelayanan seluruh keluarga dan lingkungan keluarga dan lingkungan dirumah, rumah sakit juga merupakan pusat pelatihan bagi tenaga kesehatan serta untuk penelitian biososial. Rumah sakit mempunyai unit-unit yang terkait untuk terselenggaranya pelayanan yang ada di rumah sakit, salah satunya adalah unit pelayanan rekam medis.

Rekam medis adalah berkas yang menyatakan siapa, apa, mengapa, dimana, kapan dan bagaimana pelayanan yang diperoleh seorang pasien selama dirawat atau menjalani pengobatan. Peraturan Menteri Kesehatan Republik Indonesia Nomor: 269/MENKES/PER/III/2008 menyatakan Rekam Medis adalah berkas yang berisikan catatan dan dokumen tentang identitas pasien, pemeriksaan, pengobatan, tindakan dan pelayanan lain yang telah diberikan kepada pasien (Kemenkes RI, 2008).

Mutu pelayanaan kesehatan adalah pelayanan kesehatan yang dapat memuaskan setiap pemakai jasa pelayanan kesehatan yang sesuai dengan tingkat kepuasan rata-rata sesuai dengan standar dan kode etika profesi. Penyediaan rekam medis yang cepat merupakan salah satu faktor yang dapat mempengaruhi kepuasan pasien. Semakin cepat penyediaan dokumen rekam medis sampai ke poliklinik maka semakin cepat pelayanan yang diberikan kepada pasien. Dalam meningkatkan pelayanan yang lebih bermutu diperlukan adanya standar pelayanan yang menjadi acuan dalam meningkatkan kualitas pelayanan. Salah satu standar penilaian pelayanan yaitu Standar Pelayanan Minimal. Berdasarkan Keputusan Menteri Kesehatan Republik Indonesia No.129/MENKES/SK/II/2008 tentang Standar Pelayanan Minimal Rumah Sakit menyatakan Standar Pelayanan Minimal adalah adalah ketentuan tentang jenis dan mutu pelayanan dasar yang merupakan urusan wajib daerah yang berhak diperoleh setiap warga secara minimal. Standar untuk waktu penyediaan rekam medis pelayanan rawat jalan kurang dari atau sama dengan 10 menit ( $<10$ menit), sedangkan untuk waktu penyediaan rekam medis pelayanan rawat inap kurang dari atau sama dengan 15 menit (<15 menit) (Kemenkes RI, 2008).

Peraturan Pemerintah Republik Indonesia Nomor 65 Tahun 2005 Tentang Pedoman Penyusunan dan Penerapan Standar Pelayanan Minimal BAB I ayat 6 menyatakan : Standar pelayanan Minimal yang selanjutnya disingkat SPM adalah ketentuan tentang jenis dan mutu pelayanan dasar yang merupakan urusan wajib daerah yang berhak diperoleh setiap warga negara secara minimal, Ayat 7 menyatakan: Indikator SPM adalah tolak ukur untuk prestasi kuantitatif dan kualitatif yang digunakan untuk menggambarkan besaran sasaran yang hendak dipenuh didalarn pencapaian suatu SPM tertentu berupa masukan, proses, hasil dan atau manfaat pelayanan, Ayat 8 menyatakan: Pelayanan dasar adalah jenis pelayanan publik yang mendasar dan mutlak untuk memenuhi kebutuhan masyarakat dalam kehidupan sosial ekonomi 
dan pemerintahan. Standar pelayanaan minimal ini bertujuan untuk menyamakan pemahaman tentang definisi operasional indikator kinerja, ukuran (Kemenkes RI, 2005).

Berdasarkan penelitian yang sudah dilakukan oleh Firzah Dika Andria di RSUD Dr. Soekardjo Kota Tasikmalaya pada tahun 2015 dapat diketahui bahwa sebanyak 63 dokumen $(63,64 \%)$ penyediaan dokumen Rekam Medis Pasien Lama terlambat. Diketahui bahwa ratarata waktu yang didapatkan dalam kecepatan penyediaan dokumen rekam medis pasien lama di pelayanan rawat jalan adalah 12 menit 36 detik, dengan standar deviasi 3,13, untuk waktu tercepat adalah 7,20 menit dan waktu terlama adalah 16,54 menit (Andria, 2015).

Menurut penelitian yang dilakukan oleh Valentina di RSU Imelda Pekerja Indonesia Medan tahun 2016, diketahui dengan menghitung lama waktu pendistribusian terhadap 73 berkas rekam medis rawat jalan diketahui bahwa 33 berkas rekam medis $(34,25 \%)$ telah memenuhi standar $\leq 10$ menit, dan 48 berkas rekam medis $(65,75 \%)$ belum memenuhi standar pelayanan minimal (> 10 menit) (Valentina, 2016).

Berdasarkan penelitian oleh Isti yang dilakukan pada bulan April 2016 di RSUD Tugurejo Provinsi Jawa Tengah dengan jumlah sampel 100 dokumen rekam medis masih terdapat penyediaan dokumen rekam medis yang lebih dari 10 menit sebesar $93 \%$ dengan rata-rata waktu penyediaan 19,55 menit. Sedangkan kebijakan di RSUD Tugurejo Provinsi Jawa Tengah standar pelayanan minimal waktu penyediaan dokumen rekam medis pasien rawat jalan adalah $\leq 10$ menit (Afifah, 2016).

Diketahui bahwa yang menjadi indikator sasaran mutu di RSUD Tebet salah satunya adalah waktu penyediaan rekam medis pasien poliklinik kandungan, karena nanti RSUD Tebet akan mengganti nama menjadi Rumah Sakit Ibu dan Anak (RSIA) atau lebih di fokuskan yang berhubungan dengan obgyn (kandungan). Kebijakan waktu penyediaan rekam medis pasien poliklinik kandungan di RSUD Tebet berdasarkan Standar Prosedur Operasional adalah $\leq 15$ menit yaitu waktu dari mulai pasien selesai mendaftar (waktu ditracer), proses mencari, menyiapkan, menyediakan, dan mendistribusikan, sampai dengan diterima oleh petugas poliklinik kandungan.

Berdasarkan hasil observasi awal di RSUD Tebet peneliti melakukan observasi terhadap waktu penyediaan rekam medis rawat jalan klinik kandungan sebanyak 21 rekam medis, terdapat 11 rekam medis $(52,38 \%)$ telah memenuhi SPO, sedangkan 10 rekam medis $(47,61 \%)$ yang belum memenuhi SPO di RSUD Tebet yang telah ditetapkan. Diperoleh informasi bahwa pada pelaksanaan penyediaan rekam medis rawat jalan mengalami keterlambatan dalam proses pencarian atau tidak ditemukan pada rak penyimpanan sehingga mengakibatkan rekam medis terhambat untuk didistribusikan kepada pasien dan pelayanan pasien menjadi terlambat. Keterlambatan tersebut terjadi karena berbagai hal diantaranya kurangnya rak penyimpanan, terdapat masih banyak rekam medis yang berserakan dilantai dan belum kembali dari klinik. Lama waktu tersedianya rekam medis tersebut pun bervariasi mulai dari 20 menit sampai dengan 30 menit. Masalah tersebut sangat mempengaruhi citra Unit Rekam Medis dan citra Rumah Sakit yang berpengaruh terhadap kepuasan pasien.

Berdasarkan latar belakang di atas, penulis melakukan penelitian tentang "Tinjauan Lama Waktu Penyediaan Rekam Medis Pasien Rawat Jalan Klinik Kandungan di RSUD Tebet”.

\section{METODE PENELITIAN}

Jenis penelitian ini adalah deskriptif yang bersifat kuantitatif yaitu dengan tujuan untuk menjelaskan suatu fenomena dengan menggunakan angka yang menggambarkan karakteristik subjek yang diteliti. Penelitian dilakukan secara langsung dan ditujukan untuk memperoleh waktu penyediaan rekam medis.

Populasi dalam penelitian ini adalah seluruh rekam medis rawat jalan klinik kandungan pada bulan Juni 2021. Dalam 
penelitian ini menggunakan teknik (Incidental/Convenience Sampling). Jumlah sampel yang dihitung menggunakan rumus estimasi proporsi sejumlah 105 rekam medis pasien rawat jalan klinik kandungan. Teknik pengumpulan data menggunakan wawancara, observasi dan studi pustaka. Teknik analisa data yang digunakan dalam penelitian ini yaitu data yang dikumpulkan melalui observasi dengan menghitung lama waktu penyediaan rekam medis mulai dari saat pasien selesai mendaftar (waktu ditracer) sampai dengan waktu diterima oleh petugas poliklinik kandungan.

\section{HASIL DAN PEMBAHASAN}

\section{SPO Penyediaan Rekam Medis Pasien Rawat Jalan Klinik Kandungan}

RSUD Tebet telah memiliki Standar

Prosedur Operasional untuk pelaksanaan kegiatan penyediaan rekam medis yang diterbitkan pada tanggal 4 Juni 2020. RSUD Tebet tidak mengacu pada ketentuan Standar Pelayanan Minimal yang ditetapkan oleh pemerintah, penyediaan rekam medis pasien rawat jalan poliklinik kandungan di RSUD Tebet menggunakan Standar Prosedur Operasional sebagai pedoman atau acuan bagi petugas filing. Untuk standar waktu penyediaan rekam medis rawat jalan yang digunakan pada SPO tersebut adalah $\leq 15$ menit. Waktu perhitungan dimulai saat pasien selesai mendaftar (waktu ditracer) sampai dengan waktu diterima oleh petugas poliklinik kandungan. Kegiatan yang dilakukan oleh petugas rekam medis bagian pelayanan berkas rekam medis di RSUD Tebet belum sesuai dengan Standar Prosedur Operasional yang ada, dikarenakan masih ada rekam medis yang belum tepat waktu dalam proses penyediaan rekam medis. Terdapat faktor penyebab keterlambatan yang dihadapi petugas dalam pencarian rekam medis yaitu masih terdapat rekam medis yang tidak ditemukan di rak penyimpanan pada saat dibutuhkan, sehingga petugas rekam medis sulit menemukan rekam medis yang dicari.

Adapun Standar Pelayanan Minimal (SPM) adalah ketentuan tentang jenis dan mutu pelayanan dasar dalam kecepatan penyediaan rekam medis. Standar waktu penyediaan rekam medis pelayanan rawat jalan $\leq 10$ menit, sedangkan untuk waktu penyediaan rekam medis pelayanan rawat inap kurang dari atau sama dengan 15 menit. Kecepatan penyediaan rekam medis adalah waktu penyediaan rekam medis mulai dari pasien mendaftar sampai rekam medis disediakan/ditemukan oleh petugas (Kemenkes RI, 2008).

\section{Menghitung Lama Waktu Penyediaan Rekam Medis Pasien Rawat Jalan Klinik Kandungan \\ Berdasarkan hasil penelitian yang} dilakukan terhadap proses penyediaan rekam medis rawat jalan klinik kandungan di RSUD Tebet, sebagai berikut :

Tabel 1. Persentase Lama Waktu Penyediaan Rekam Medis Rawat Jalan Klinik Kandungan

\begin{tabular}{lcc}
\hline $\begin{array}{l}\text { Waktu } \\
\text { Penyediaan } \\
\text { Rekam Medis }\end{array}$ & Jumlah & Persentase \\
\hline $\begin{array}{l}\text { Tepat Waktu } \\
\text { ( } \leq 15 \text { menit) }\end{array}$ & 48 & $45,71 \%$ \\
$\begin{array}{l}\text { Tidak Tepat } \\
\text { Waktu (>15 }\end{array}$ & 57 & $54,28 \%$ \\
menit) & & \\
\hline Total & $\mathbf{1 0 5}$ & $\mathbf{1 0 0 \%}$ \\
\hline
\end{tabular}

(Sumber: Hasil Pengamatan Peneliti di RSUD Tebet bulan Juni, 2020)

Berdasarkan hasil perhitungan waktu penyediaan 105 rekam medis pasien Klinik Kandungan di RSUD Tebet selama 5 hari dengan jumlah rata-rata perharinya 21 rekam medis, didapati total waktu 1.646 menit dengan rata-rata waktu penyediaan rekam medis 15 menit 67 detik. Terdapat 48 rekam medis $(45,71 \%)$ yang waktu penyediaannya $\leq 15$ menit yang telah memenuhi SPO (tepat waktu), sedangkan 57 rekam medis $(54,28 \%)$ mengalami keterlambatan penyediaan yaitu $>15$ menit atau belum memenuhi SPO (tidak tepat waktu). Waktu tercepat dalam penyediaan rekam medis yaitu 10 menit dan waktu terlama yaitu 25 menit.

Hasil presentase waktu penyediaan rekam medis ini membuktikan bahwa masih banyak 
rekam medis yang ditemukan >15 menit. Ketepatan waktu penyediaan rekam medis rawat jalan menjadi tanggung jawab petugas rekam medis untuk mengusahakan pelayanan lebih baik di RSUD Tebet. Dampak dari ketepatan waktu penyediaan rekam medis rawat jalan berpengaruh pada kepuasan pasien yang berkunjung, serta meningkatkan mutu pelayanan terhadap pelanggan dan meningkatkan citra RSUD Tebet di mata masyarakat.

\section{Faktor-faktor Penyebab Keterlambatan Rekam Medis Pasien Rawat Jalan Klinik Kandungan}

Berdasarkan data yang diperoleh dari hasil wawancara dengan kepala rekam medis terhadap proses penyediaan rekam medis rawat jalan klinik kandungan, diperoleh kesimpulan hal-hal yang memperlambat waktu penyediaan rekam medis rawat jalan sering disebabkan oleh hal-hal sebagai berikut :

1. Kapasitas rak penyimpanan sudah terlalu penuh, rekam medis masih berada di lantai belum di taruh kembali ke rak penyimpanan, dan sering ditemukan rekam medis menempel pada rekam medis lainnya.

2. Letak ruang rak penyimpanan rekam medis terpisah menjadi 2. dimana ruang penyimpanan 1 tergabung dengan ruang rekam medis, dari nomor rekam medis 00-75, sedangkan di ruang penyimpanan 2 berada di sebelah ruang radiologi, dari nomor rekam medis 76-99. Rekam medis tersebut disimpan secara sentralisasi, baik untuk pasien rawat inap, rawat inap, gawat darurat, atau pelayanan lainnya disimpan di ruang penyimpanan 1 dan 2 .

3. Rekam medis masih berada di ruang rawat inap saat pasien akan kontrol rawat jalan. Hal ini karena rekam medis masih dibagian pengolahan rekam medis belum disimpan kembali ke rak penyimpanan.

\section{SIMPULAN}

RSUD Tebet telah memiliki Standar Operasional Prosedur untuk pelaksanaan kegiatan penyediaan rekam medis. RSUD Tebet tidak mengacu pada ketentuan Standar Pelayanan Minimal yang ditetapkan oleh pemerintah, penyediaan rekam medis pasien rawat jalan klinik kandungan di RSUD Tebet menggunakan Standar Prosedur Operasional sebagai pedoman atau acuan. Untuk standar waktu penyediaan rekam medis rawat jalan yang digunakan pada SPO tersebut adalah $\leq 15$ menit.

Waktu penyediaan rekam medis yang diamati dari 105 rekam medis pasien rawat jalan klinik kandungan dengan rata-rata waktu penyediaan 15 menit 67 detik. Ditemukan 48 rekam medis $(45,71 \%) \leq 15$ menit yang telah memenuhi SPO (tepat waktu), dan 57 rekam medis $(54,28 \%)>15$ menit yang belum memenuhi SPO (tidak tepat waktu). Waktu tercepat adalah 10 menit dan waktu terlama adalah 25 menit. Maka dapat dikatakan bahwa ketepatan waktu penyediaan rekam medis melebihi Standar Prosedur Operasional yang ada di RSUD Tebet.

Faktor-faktor yang menyebabkan keterlambatan dalam penyediaan rekam medis pasien rawat jalan klinik kandungan berdasarkan hasil pengamatan lamanya waktu penyediaan rekam medis yaitu, kapasitas rak penyimpanan sudah terlalu penuh, rekam medis masih berada di lantai belum di taruh kembali ke rak penyimpanan, sering ditemukan rekam medis menempel dengan rekam medis lainnya. Sehingga rekam medis ketika diperlukan sulit ditemukan dan sulit diambil, letak ruang penyimpanan terpisah menjadi 2 , sehingga petugas harus berulang kali bergerak ke ruang penyimpanan 2 sebelum didistribusikan ke poliklinik, belum dikembalikannya rekam medis rawat inap ke rak penyimpanan, sehingga petugas harus mengambil ke ruang rawat inap bagian pengolahan rekam medis.

\section{DAFTAR RUJUKAN}

Afifah, N. I. (2016). Penyediaan Dokumen Rekam Medis Pasien Rawat Jalan Pada Klinik Syaraf RSUD Tugurejo Provinsi Jawa Tengah Periode Triwulan III Tahun 2016. 
6 Indonesian Journal of Health Information Management (IJHIM), Vol. 2 No. 1 (2022),

Andria, F. D. (2015). Tinjauan Penyediaan Dokumen Rekam Medis Di RSUD Dr. Soekardjo Kota Tasikmalaya. Jurnal Manajemen Informasi Kesehatan Indonesia, 3(2), 51-57.

Kemenkes RI. (2005). Peraturan Pemerintah Republik Indonesia Nomor 65 Tahun 2005 Tentang Pedoman Penyusunan dan Penerapan Standar Pelayanan Minimal. 46(2), 113-116.

Kemenkes RI. (2008a). Peraturan Menteri Kesehatan Republik Indonesia Nomor 129 Tahun 2008 tentang Standar Pelayanan Minimal. Standar Pelayanan Minimal Rumah Sakit, 49, 69-73.

Kemenkes RI. (2008b). Peraturan Menteri Kesehatan Republik Indonesia Nomor 269/MENKES/PER/III/2008 tentang Rekam Medis (p. 7).

Kemenkes RI. (2010). Peraturan Menteri Kesehatan Republik Indonesia Nomor 340/Menkes/Per/III/2010 Tentang Klasifikasi Rumah Sakit. 116.

Valentina. (2016). Tinjauan Lama Waktu Pendistribusian Rekam Medis Pada Pasien Rawat Jalan Di Rsu Imelda Pekerja Indonesia Medan Tahun 2016. Jurnal Ilmiah Perekam Dan Informasi Kesehatan; Vol 2 No 1 (2017), 2(1), 248-254. 